\title{
How do Migrants Choose their Destination Country? An Analysis of Institutional Determinants
}

\author{
WIDO GEIS \\ SILKE UEBELMESSER \\ MARTIN WERDING
}

CESIFO WORKING PAPER NO. 2506

CATEGORY 4: LABOUR MARKETS

DECEMBER 2008

\footnotetext{
An electronic version of the paper may be downloaded

- from the SSRN website:

www.SSRN.com

- from the RePEc website:

- from the CESifo website:

www.RePEc.org

www.CESifo-group.org/wp
} 


\title{
How do Migrants Choose their Destination Country? An Analysis of Institutional Determinants
}

\begin{abstract}
For a long time, migration has been subject to intensive economic research. Nevertheless, empirical evidence regarding the determinants of migration still appears to be incomplete. In this paper, we analyze the effects of socio-economic and institutional determinants, especially labor-market institutions, on migrants' choices. Based on a large data set constructed from micro-data for France, Germany, the UK and the US, we study their decisions to migrate to one of the four countries using a Multinomial Choice framework. Our estimates confirm a number of conventional results such as positive effects of wages and immigrant networks and negative effects of unemployment rates. In addition, we find that employment protection, union coverage and unemployment benefits have positive effects on migration. Also good education and health systems tend to attract migrants, while generous pension systems may deter them. Based on separate estimations for high- and low-skilled migrants, there is evidence that the effects of labor-market institutions differ across skill groups.
\end{abstract}

JEL Code: A00, J21, J31, J61.

Keywords: migration, labour-market institutions, micro-data, Multinomial Choice.

Wido Geis

Ifo Institute for Economic Research at the University of Munich

Poschingerstrasse 5

Germany-81679 Munich

geis@ifo.de
Silke Uebelmesser

Center for Economic Studies and CESifo at the University of Munich

Schackstrasse 4

Germany-80539 Munich

uebelmesser@lmu.de

\author{
Martin Werding \\ Chair of Social Policy and Public Finance \\ University of Bochum \\ Germany - Bochum \\ Martin.Werding@ruhr-uni-bochum.de
}

December 2008 


\section{Introduction}

Moving to another country often implies fundamental changes for the life of migrants. They have to build up a new social network and get accustomed to a new institutional framework. Usually, migration is not the result of a spontaneous decision, but the outcome of a long decision process. Therefore, the institutions of possible destination countries should at least play some role in this process. For instance, if public regulation impedes labor-market entry for "outsiders", migrant workers should ceteris paribus prefer destination countries with more flexible labor markets. Similarly, older persons should prefer countries that give them access to a better health-care system, and parents should prefer countries that offer their children better education. The aim of our paper is to analyze whether these and other institutions play a role for the migration decision and to quantify their effects.

How migrants choose their destination country is an interesting research question per se. In addition, the answer to this question has important implications for migration policy. On the one hand, it can help to estimate migration potentials for the case of unrestricted mobility which, in turn, may have a strong influence on the final decision about immigration policy if a country is considering some modifications. On the other hand, it can have an influence on the assessment of migration regulations already in place. A prominent example for this is the large inflow of Polish people to the UK after the EU enlargement in 2004. It is argued that a large part of these people would have come to Germany, if Germany had also opened its labor market immediately (Baas and Brücker 2007). However, in the relevant years unemployment in the UK was much lower than in Germany. Thus, one could also argue that these people would have gone to the UK anyway because of their better labor-market prospects there. Last but not least, knowledge about the determinants of migration decisions can help policy makers to design effective programs to attract specific groups of foreigners (such as the British "Highly Skilled Migrant Programme" the H1B visa in the US, or the German "Green Card" for IT specialists).

Over the last few years, a series of papers have emerged that analyze the determi- 
nants of migrants' location choices (e.g., Pedersen et al. 2008; Mayda 2007; Docquier et al. 2007). These papers are based on international macro-data panels. ${ }^{1}$ Besides unemployment rates and GDP per capita, they find that distance plays an important role for migration decisions. In addition, a common language and colonial ties obviously have a positive effect on the choice of a particular destination country. However, the use of aggregate data carries some problems, as the determinants of migration most likely differ between population groups (e.g., labor-market access may vary by qualifications and experience; the quality of the destination country's education system is more important for young parents than for childless retires; etc.). ${ }^{2}$ Therefore, we follow another route and build our analysis on micro-data.

Unfortunately, no large international micro-data base exists that could be used for our purposes. ${ }^{3}$ We therefore construct our own data set, merging micro-data from four of the most important immigration countries, namely France, Germany, the UK and the US. ${ }^{4}$ Because of the limited number of countries covered, we can only analyze migrants' choices conditional on that they are willing to migrate at all and that they end up living in one of these four destination countries. ${ }^{5}$ We combine these micro-data with data regarding a number of institutions that potentially have an impact on the location decision. Using a Multinomial Choice framework, we then estimate the effects of these institutions on the choice of a particular destination among our four countries. From a technical perspective, Constant and D'Agosto (2008) is the paper on international migration that is probably closest to ours. Based on a data set covering Italian scientists living abroad, they analyze

\footnotetext{
${ }^{1}$ See Lundberg (1993) for an earlier study based on cross-section data.

${ }^{2}$ Docquier et al. (2007) differentiate between high-skilled and low-skilled migrants, whereas the other researchers look at total migration between two countries.

${ }^{3}$ The European Labour Force Survey would be such a data base but, in its publicly accessible form, it contains no information on the origin of migrants.

${ }^{4}$ Defoort (2007) states that, together with Canada and Australia, these countries attract $77 \%$ of all migrants to the OECD world.

${ }^{5}$ For an analysis of the unconditional migration decision, one would also have to observe populations and institutions in the source countries, and one should probably be able to add more destination countries.
} 
the determinants of their choice of a destination country. In contrast to our approach, however, they only use individual characteristics and no general features of the destination countries as explanatory variables. There is a number of papers using a similar approach to determine the regional distribution of immigrants within their destination countries (Åslund 2005; Bartel 1989; Jaeger 2000; and Bauer et al. 2005; 2007). Since political and economic institutions do not vary very much across regions of one country, whereas they differ substantially across countries, the results are only partially comparable with ours.

To date, the impact of institutions on migration decisions has hardly been studied in a systematic way. ${ }^{6}$ Thus, our results offer interesting and important new insights regarding the determinants of migration decisions. Our more conventional findings are that wages and migrant networks have a positive effect on the probability to migrate to a particular country, while the unemployment rate has a negative effect. The income tax wedge negatively affects migration, and the same applies to generous pension benefits, while good education systems and good health-care systems appear to have a positive impact. In addition, we find that the labor-market institutions which we consider - employment protection, union coverage and unemployment benefits - all have positive effects on the migration decision. Running separate estimations for qualified and low-skilled migrants, we find for most institutions the same effects. However, union coverage and unemployment benefits now negatively affect the migration choice for qualified migrants, while the positive effects are again there for low-skilled migrants. Also, the positive effect of employment protection remains for both groups.

The paper is organized as follows. In the next section, we explain how our data set is constructed. In section 3, we present a number of descriptive results regarding immigration to the four countries of our analysis. Section 4 deals with determinants of migration and, in particular, with institutions that may have an influence on migration decisions. In section 5, we discuss our estimation strategy, and in section 6 , we present

\footnotetext{
${ }^{6}$ Borjas (1999) investigated the role of welfare benefit entitlements for migration within the US, which led to his "welfare magnet" hypothesis. More recently, Docquier et al. (2007) found a positive effect of social expenditure and health expenditure. We are not aware of any studies investigating labor-market institutions as potential determinants of migrants' location choices.
} 
our results based on the full sample and on separate estimations for qualified and low-skilled migrants. Section 7 concludes.

\section{The data set}

Our data set combines micro-data from large official surveys of the British, French, German and US population. The source of our French data is the Enquête Emploi en Continu 2005, a representative survey of about $0.5 \%$ of the French population. The German data are taken from the Mikrozensus 2005, a representative 1\% survey (0.7\% in the Scientific Use File we are using). The British data are from the (British) Labour Force Survey for the first quarter of 2005 , a survey of about $0.2 \%$ of the population in the UK. For the US, we use the American Community Survey 2005, a representative 1\% survey of the US population. In order to analyze the motivation of migrants, flow data would actually be preferable to stock data. However, existing flow data generally contain much less information and are less precise than stock data. Therefore, we rely on data of the latter type, implying that we actually do not analyze decisions to migrate to another country, but decisions to migrate to another country and stay there until the sampling period.

An important preliminary step is to find a proper definition of migrants. Immigrants could be defined as persons holding one or more foreign nationalities. Yet, this approach is problematic as naturalization policies of the four countries differ substantially. For instance, the German naturalization policy is much more restrictive than the American one. Hence, looking at individuals with foreign nationalities could lead to biased results. Defining immigrants by their country of birth circumvents this problems. However, since foreign-born children whose parents are both natives are then classified as immigrants, this definition can also lead to problems, e.g., if a non-marginal part of the foreign-born population are children of armed forces positioned abroad. Therefore, we choose the following approach: we define immigrants as foreign-born people, but re-classify persons with two native parents as natives. ${ }^{7}$ The effect of this re-classification on the overall

\footnotetext{
${ }^{7}$ For the UK, respectively, we re-classify persons who state to be "ethnically British".
} 
number of immigrants is small, but their composition changes notably (see Geis et al. 2008 for more details).

In the case of Germany, we have to deal with two specific issues. First, in the German data the country of birth of immigrants is not recorded. We therefore use the nationality, respectively the nationality before naturalization, as a proxy for the country of birth. The second issue is related to the "(Spät-)Aussiedler" legislation. According to this legislation, persons with German ancestors (who sometimes emigrated centuries ago, mainly to countries in Eastern Europe) can acquire the German nationality immediately upon arrival in Germany. After the fall of the "Iron Curtain", a large number of "Spät-Aussiedler" came to Germany (Koller 1997). Yet, in spite of their quantitative importance, official statistics in Germany hardly collect any data on this group. In our data set, we are able to identify them as immigrants, ${ }^{8}$ but we cannot assign them a country of birth.

For the source countries, or countries of birth, we choose the following classification: EU countries, non-EU Europe (including Russia and Turkey), West Asia (from Lebanon to Iran), East Asia and Oceania, Africa, Latin America, Canada ${ }^{9}$ and "unclassified"10. A more detailed differentiation is not possible, due to existing classifications in the German and French data sources. For the econometric analysis, people who migrate between our four destination countries also have to be excluded, ${ }^{11}$ but the descriptive results reported in the next section cover these migrants as well.

As a further step, we have to standardize a number of other variables we are using. The only institution for which the standardization is not trivial is education. Here, we classify educational attainments of our observations using the International Standard

\footnotetext{
${ }^{8}$ Alternative explanations for why Germans with German parents should have "migrated" to Germany are highly unlikely. For instance, since World War II Germany had hardly any armed forces positioned abroad. Also, all persons with German nationality who came to Germany before 1949, mostly as refugees from former parts of the country, are automatically defined as natives.

${ }^{9}$ In the case of Germany, Canadians are excluded, as we cannot distinguish them from US Americans.

${ }^{10}$ By far the largest part of them being German "Aussiedler".

${ }^{11}$ The reason is that, with respect to migration between the four countries, we can only observe potential outcomes of migration to three destination countries. Decisions to stay in the home country or to migrate there, though vastly different, cannot be told apart.
} 
Classification of Education (ISCED) 1997. For the German data, we use the algorithm proposed by Schrödter et al. (2006) and for the American data the mapping between years of schooling and ISCED levels given in Institute for Education Sciences (2007). The French data already contain education levels in the ISCED classification. For the British data, our re-classification follows the LFS User Guide (2007) with two deviations. ${ }^{12}$ Also, we do not use all ISCED levels, but form four categories: no secondary educational attainment (ISCED 0-1), lower-secondary educational attainment (ISCED 2), upper-secondary and post-secondary non-tertiary educational attainment (ISCED 3-4) and tertiary educational attainment (ISCED 5-6). Differentiations between ISCED 3 and 4 and between ISCED 5 and 6 are hardly comparable across countries.

In the last step, we merge the standardized variables from the four national data sets to form one large data base, using the weights from the original data sources. As these weights make the data sets representative for the different countries, our data base should also be representative. Since the Enquête Emploi does not contain information on persons who are younger than 15, our descriptive results only refer to people aged 15 and over. For the econometric analysis, we further drop all individuals who are younger than 25 , as many of these people have not yet reached their final educational level. Including these observations could thus lead to biased estimates.

\section{Some descriptive results}

Before turning to the econometric analysis, we present some descriptive statistics from our data. These statistics do not only serve as background information for our estimation results, they are also interesting in themselves. Applying a consistent definition of migrants,

\footnotetext{
${ }^{12}$ First, we classify people who state to have been in school, but have not acquired any formal degree as ISCED 1, not ISCED 2. Second, we do not classify people who state to have "other qualifications" as ISCED 3, but assign them the median ISCED level of people with the same age and the same (last) occupation. For this, we use the SOC (Standard Occupational Classification) 2000 unit-level classification which distinguishes between 353 different occupations. An assignment of educational levels is necessary, as most foreign degrees are recorded as "other qualification" in the British LFS.
} 
our data give a very precise picture of the migrant population in the four countries. ${ }^{13}$

Comparing the shares of immigrants in the population aged 15 and older in the four countries already leads to a surprising result ( $c f$. table 1 ). We find the highest share of immigrants in Germany, with $16.8 \%$, followed by the US with $14.4 \%$, France with $8.5 \%$ and the UK with $8.2 \%$. The large share of immigrants in Germany, a country that is actually well-known for its restrictive immigration policy, has two reasons. The German "guest-worker" agreements with Turkey, Italy, Yugoslavia, Spain and Portugal caused a large immigration wave between 1955 and 1973, and has led to a continuous in-flow of migrants due to family re-unification programs ever since. In addition, and probably even more important, is the "(Spät-)Aussiedler" legislation mentioned above. The other shares are in line with common expectations: the US as an "immigration country" have a much larger share of immigrants than France and the UK. Effects of the recent, more liberal immigration policy in the UK, especially the opening of the labor market for people from Eastern Europe in 2004, are not yet visible in the data from 2005.

Table 1 also gives an overview over the most important countries of origin of the migrants to the four countries. In France, these are above all neighboring countries in Europe and Northern Africa. In Germany, Southern and Eastern European countries are the most important countries of origin; at the same time, one third of all German immigrants cannot be classified, most of them being "(Spät-)Aussiedler" in all likelihood. In contrast to Germany and France, the most important source countries of immigrants to the UK are former colonies outside Europe, together with Ireland and Poland. For the US, countries in Central and Caribbean America and large East Asian countries are the most important ones. It is remarkable that almost one third of the American immigrant population comes from Mexico. In none of the European countries, immigration is similarly concentrated on one country of origin. However, the European countries also differ with respect to the concentration: $38.8 \%$ of the immigrants to France, but only $26.8 \%$ and $24.5 \%$ of the immigrants to Germany and the UK respectively are from the three

\footnotetext{
${ }^{13}$ For a larger set of descriptive results that are based on the same data base, see Geis et al. (2008).
} 
most important countries of origin.

There are not only differences regarding the countries of origin of immigrants, but also regarding their structure in terms of educational attainments. Table 2 shows how immigrants aged 25 to 54 are distributed over the educational groups defined above. For comparison, we add the corresponding distribution of natives. The share of "highskilled" immigrants (ISCED 5+6) is highest in the US, followed by the UK, Germany and France. The picture is similar for "qualified" immigrants, i.e., for those with at least an upper secondary degree (ISCED 3-6). Obviously, the Anglo-Saxon countries attract people with higher qualifications than the countries in Continental Europe. At the same time, immigrant populations within a particular country are far from being homogeneous in this respect. For instance, the share of high-skilled immigrants from Mexico to the US is far below that of natives; this is also the case for immigrants from other Latin American countries, but the difference is much smaller; however, the share by far exceeds that of natives for immigrants from non-Latin American countries. All in all, this leads to a $U$-shaped pattern of educational attainments of immigrants to the US. In Europe, there are similar differences between various immigrant groups, e.g., between Turkish and other immigrants to Germany, but they are much smaller than in the US. ${ }^{14}$

A further interesting aspect is the economic integration of immigrants. As a rough measure, we include unemployment rates (following the ILO definition) differentiated by educational attainments in table 2. In all European countries, unemployment rates of immigrants are much higher than those of natives, but in the UK they are still much lower than in France and Germany. In the US, however, unemployment rates of immigrants fall short of those of natives, except for the highest education level (ISCED 5+6). Note that this cannot be explained by different selections into unemployment and non-participation, since participation rates of immigrants are not smaller compared to those of natives in the US than in Europe. These observations clearly indicate that all the European countries we consider have more difficulties in integrating immigrants into their labor markets than

\footnotetext{
${ }^{14}$ See, again, Geis et al. (2008) for more details.
} 
the US. They also show that economic integration differs across skill groups. When analyzing the determinants of migration, it is thus less appropriate to rely on countrywide averages. Specific information, i.e. information differentiated with respect to skill groups for example, is of value, which we are able to use in the following due to the micro-structure of our data.

\section{Determinants of migration}

In the economic migration literature, wages and unemployment rates are generally considered the most important determinants of migration (see the seminal papers by Sjaastad 1962; Todaro 1969; Harris and Todaro 1970). As these two factors vary strongly across different population groups, detailed data are needed for a meaningful econometric analysis.With our micro-data, we are able to include differentiated data. For this, we use the unemployment rates following the ILO definition and calculate specific unemployment rates of immigrants differentiated by education and gender.

However, obtaining consistent data on wages is very difficult in general and still far from easy even with our micro-data, since the wage data provided in our data sets are not comparable across countries. To generate wage information from our four national data sources which are as consistent as possible, we proceed as follows: In a first step, we calculate wages per hour using information on wage earnings and working hours contained in all datasets. As our German dataset actually contains income and not wage data, we consider only persons stating to have no income other than wages for this. ${ }^{15}$ In a next step, we calculate wages of immigrants for the various gender-education groups relative to the respective average wages in each country. In the last step, we multiply these relative wages of immigrants with data on GDP per capita (from OECD 2007a). We cannot directly compare our intermediate results regarding wages per hour, since we have information on net wages for the European countries, while we observe gross wages in the US. Note that

\footnotetext{
${ }^{15}$ Note, that after the further steps described in the following, we assign wage information also to those Germans with other income sources, which enables us to again use the complete dataset.
} 
this means that the dispersion of our wage measure for the US is probably exaggerated compared to that in the European countries. Still, we think our differentiated measure of wages is superior to (uniform) GDP per capita which is used in many other studies on the determinants of migration (see, e.g., Pedersen et al. 2008; Mayda 2007; Docquier et al. 2007).

Another very important determinant of migration are migrant networks (see Munshi 2003 for a comprehensive analysis of Mexican networks in the US). These networks facilitate migration as they transmit detailed information about the destination country and provide a social network once new migrants have arrived. Furthermore, where such networks exist, many people have the opportunity to use preferential family re-unification programs to immigrate. In our econometric analysis, we use the share of persons from a specific source country in the population of the destination country as a measure of the strength of the migrant network. Due to data limitations, we can actually do so only for immigrant groups representing at least $0.2 \%$ of the population in the destination country. This need not be a problem, however, as smaller groups are probably lacking the critical mass to deliver the benefits of a network. As the effect of the size of the network on migration decisions may not be linear - in smaller networks, additional persons are probably more important than in larger ones - we also include the square of this measure.

In addition, immigration policy and the openness of a country for immigrants may also influence the migration decision. However, immigration policy is difficult to measure - immigration laws are usually complex and rather case-specific - and there does not exist a consistent indicator of immigration policy, or openness, for all our four destination countries. ${ }^{16}$ Thus, we cannot observe this determinant directly. Yet, as one should assume that in the long run a more open country attracts more immigrants, we use the total share of foreign-born persons in a country as a rough measure for its openness to migrants.

Beside the factors discussed so far, there is a host of other potential determinants of

\footnotetext{
${ }^{16}$ For the European countries, the British Council and Migration Policy Group (2007) has proposed such an indicator, called MIPEX. However, it does not contain any information regarding the US.
} 
migrants' location choices. ${ }^{17}$ For instance, unemployment benefits should also have an influence on migration decisions, since expected income in the destination country is basically given by the employment rate times wages plus the unemployment rate times these benefits. However, quantifying unemployment benefits is complicated as benefit entitlements often depend on the time a person has been (un-)employed. For our set-up, the most convincing measure that is available are average replacement rates for the first five years of unemployment as provided by the OECD (2004). ${ }^{18}$ The role of unemployment benefits may also depend on the unemployment rate in a given country. If unemployment is low, migrants expect to find work, and benefits have next to no influence on the decision for this country. However, if unemployment is high, migrants expect to become unemployed with some probability, and benefits really matter for their potential income. To control for this effect, we interact the replacement rate with the unemployment rate.

Other factors which affect expected income in the destination country are income taxes and social-security contributions. As we are unable to fully capture the different schemes by which these levies redistribute income from highly productive to less productive individuals we use total tax wedges (including social-security contributions), differentiated for average high- and low-income workers without children and for average workers with children, as indicated by the OECD (2006b) as a measure for the fiscal burdens that arise.

There are further labor-market institutions that may also have an impact on location decisions of migrants. For people who have to build up a new existence abroad, job security is probably an important criterion. A good measure for job security is the (overall) employment protection legislation (EPL) indicator calculated by the OECD (2004). It ranks the legal requirements for dismissals in various countries on a scale from 0 to 6 , higher values indicating stricter regulation. In many countries, trade unions are another important labor-market institution. To capture their power, we use the share of employment contracts covered by collective wage agreements (OECD 2004). Employment

\footnotetext{
${ }^{17}$ Table 3 gives an overview of the institutional determinants we include in our analysis.

${ }^{18}$ Unfortunately, these data do not allow for a differentiation by educational levels. Replacement rates may be higher for low-skilled than for high-skilled individuals if part of the benefits are lump-sum.
} 
protection and union power, though attractive for those covered or represented, may also lead to insider-outsider problems. Therefore, we additionally interact them with the unemployment rate.

When considering to migrate, people may not only look at their labor-market prospects but also at institutions in other areas. One important factor may be the health-care system in potential destination countries. We effectively use infant mortality (OECD 2007b) as a measure for the quality of health-care systems. For young families (and persons who think about having children), the education system in the destination country may also play a role. We thus include PISA science scores (OECD 2006a) as a measure for the quality of the education system. At the same time, people who do not (plan to) have children may not prefer high-quality public education as this requires higher taxes. The education system of a destination country can also affect the choice of potential immigrants for other reasons. Countries with a high share of high-skilled individuals are potentially more innovative than others and therefore likely to generate higher growth. We therefore include the share of people with a tertiary degree (ISCED $5+6$ ) from our micro-data as a measure for the skill structure.

Last but not least, a generous old-age pension system could also have a positive impact on the location choice; but since migrants first have to pay a correspondingly higher amount of contributions, the effect can also be negative. ${ }^{19}$ In any case, we use pension replacement rates differentiated by wage brackets (OECD 2007c) to control for this aspect. There are certainly many more institutions that may also play a role for the decision to migrate to a particular country. We believe, however, that the institutions described here (see also table 3) are the most important ones.

\footnotetext{
${ }^{19}$ This is actually the prediction derived from simulations of the financial effects of public pension schemes for migrants in Werding and Munz (2005).
} 


\section{$5 \quad$ Estimation strategy}

For the estimation, we use a combination of a Conditional and a Multinomial Logit Model (CMNL). ${ }^{20}$ The basic idea of the model is that among a range $J$ of options - in our case, among destination countries, individuals choose the one that offers them the highest utility, $V_{i j}$; here, $i$ denotes the individual and $j$ the option. This utility, in turn, depends on option-dependent explanatory variables, $X_{i j}$, and on option-invariant ones, $Z_{i}$. Assuming a linear relation and adding an error term, utility levels are represented by the following equation:

$$
V_{i j}=X_{i j}^{\prime} \beta+Z_{i}^{\prime} \gamma_{j}+\epsilon_{i j}
$$

The observed variable $y_{i j}$ indicates which option an individual has chosen. Thus, for $k \in J, y_{i k}=1$ and $y_{i \neg k}=0$ if $V_{i k}=\max _{j}\left(V_{i j}\right)$. Furthermore, it is assumed that the error terms, $\epsilon_{i j}$, are independent and log-Weibull-distributed; the density of this function is $e^{\left(-\epsilon_{i j}-e^{-\epsilon_{i j}}\right)}$. It can be shown that the probability function has the following form (see Amemiya 1981):

$$
p_{i j}=\operatorname{Prob}\left(y_{i j}=1 \mid X, Z\right)=\frac{e^{X_{i j}^{\prime} \beta+Z_{i}^{\prime} \gamma_{j}}}{\sum_{l=1}^{J} e^{X_{i l}^{\prime} \beta+Z_{i}^{\prime} \gamma_{l}}}
$$

For the estimation, this CMNL has to be transformed into a pure Conditional Logit Model. Following Cameron and Trivedi (2005), we use the following probability function for the estimation:

$$
p_{i j}=\operatorname{Prob}\left(y_{i j}=1 \mid X, Z^{*}\right)=\frac{e^{X_{i j}^{\prime} \beta+Z_{i j}^{*^{\prime}} \gamma^{*}}}{\sum_{l=1}^{J} e^{X_{i l}^{\prime} \beta+Z_{i l}^{*} \gamma^{*}}}
$$

where $Z^{*}$ is the Kronecker product of $Z$ and a $J \times J$ identity matrix $I, Z^{*}=Z \otimes I$, and $\gamma^{*}=\left[\mathbf{0}^{\prime}, \gamma_{2}^{\prime}, \ldots, \gamma_{J}^{\prime}\right] ; \gamma_{1}=\mathbf{0}$ is a normalization. The model is estimated by maximum likelihood. The resulting first-order condition is given by:

$$
\sum_{i=1}^{N} \sum_{j=1}^{M} y_{i j}\left(\mathbf{x}_{i j}-\overline{\mathbf{x}}_{i}\right)=0
$$

\footnotetext{
${ }^{20}$ Although this combination is well-known in the econometric literature, it has no particular name. It is sometimes called Mixed or Multinomial Logit Model, but these labels also refer to other models.
} 
with $\overline{\mathbf{x}}_{i}=\sum_{l=1}^{m} p_{i l} \mathbf{x}_{i j}$. The marginal effects of changes in the option-dependent explanatory variables can be calculated as follows ( $c f$. Cameron and Trivedi 2005):

$$
\frac{\partial p_{i j}}{\partial \mathbf{x}_{i k}}=p_{i j}\left(\delta_{i j k}-p_{i k}\right) \beta
$$

The equation gives the effect of a change in the independent variable for option $k$ on the probability that option $j$ is chosen; $\delta_{i j k}$ is equal to 1 if $j=k$ and 0 otherwise. Elasticities are given by:

$$
\frac{\partial p_{i j}}{\partial \mathbf{x}_{i k}} \frac{\mathbf{x}_{i k}}{p_{i j}}=\mathbf{x}_{i k}\left(\delta_{i j k}-p_{i k}\right) \beta
$$

It can be shown that the resulting estimates are consistent, asymptotically normal and asymptotically efficient. A characteristic of the Conditional Logit Model which is often criticized is the independence of irrelevant alternatives. In our case, this is actually an advantage, as we can only observe a limited number of countries. Our results would be of very limited relevance if the possibility to go to Spain had an effect on choices between Germany and the US.

The low variation in our institutional variables - many of them are country-specific - clearly presents a challenge. On the one hand, considering all of them in a single regression is not possible, as this would lead to multi-collinearity. On the other hand, more detailed information is not available, and adding more destination countries to our data set is all but easy. Therefore, we choose to expand the number of estimations using different combinations of the various institutions captured by our data. The following individual-specific variables are included in all regressions: level of education, gender, age (and age squared), (squared) years since migration and region of the country of birth. Furthermore, all regressions contain information on wages, unemployment rates and the (squared) size of migrant networks, as these are variables which are conventionally found to have a strong impact on migrants' location decisions.

In a first step, the institutional variables are then included one by one in the regressions. As there could also be interactions between the institutions, we repeat the estimations with all possible pairs and triplets of institutions (while including four or more institutional variables in a single estimation may lead to multi-collinearity). If the 
dispersion of estimated coefficients for an explanatory variable is not too large, the estimate should not be affected by an omitted-variables problem. We then infer the direction and magnitude of the effects from the median coefficients we obtain. Similar approaches have been proposed in other areas of economics and social sciences (for instance, Sala-iMartin 1997 uses a similar approach to explain economic growth; Hegre and Salaris 2007 do the same to explain civil wars). We use the extreme-bound criterion proposed by Leamer (1985) to test the significance of our estimates. ${ }^{21}$

\section{Estimation results}

The results of regressions in which we control for wages, unemployment rates, networks (squared) and one further institutional variable (for a complete list, see table 3) are shown in table 4 . The variables are all significant at the $1 \%$ level. Due to space limitations, estimates for individual-level characteristics are not reported; except for the country-of-birth dummies for Canada and for those not classified (mainly German "Spät-Aussiedler"), they are also significant at the $1 \%$ level. The pseudo- $R^{2}$ of about 0.64 indicates that our explanatory variables are indeed important determinants of migrants' choices of a destination country. Most variables have positive effects, the exceptions being the unemployment rate, infant mortality, the tax wedge, the pension replacement rate and the share of high skilled. There are also negative effects of the squared network effect and the interaction terms of employment protection, unemployment benefits and union coverage with the unemployment rate.

Table 5 displays the median results derived from the full set of our estimations, i.e., where we control for one, two or three institutional variables in addition to wages, unemployment rates and networks (squared). Except for the share of high skilled, the median

\footnotetext{
${ }^{21}$ Lower (upper) extreme bounds are given by minimum (maximum) estimates minus (plus) two times the corresponding standard deviation. We also tried to apply the criterion proposed by Sala-i-Martin (1997). However, in our case - with low standard errors of the estimates, but relatively high variation over specifications - this criterion is inappropriate, as it attaches no weight to the variation of coefficients over specifications.
} 
results of our estimates all have the same signs as those reported in table $4{ }^{22}$ This indicates that the estimated effects are stable across specifications. Furthermore, most of our results are in line with expectations. For instance, for wages we find the expected positive effect and for unemployment rates the expected negative effect. Immigrant networks have a positive effect, but their impact is decreasing as the squared network variable has a negative sign. This indicates that networks really facilitate immigration to a country; however, when the network is already large, an increase in its size has hardly an additional positive effect. We also find that open countries, i.e., those with a high share of foreign-born people, are indeed more attractive for immigrants than countries with a low share.

Other results are less clear a priori, hence potentially more interesting. Employment protection, union coverage and unemployment benefits have positive effects, indicating that migrants prefer destination countries where they are protected from labor-market risks. It also implies that the immigrants in our data set did not expect to become outsiders in the labor market of their destination country. Otherwise, these measures should be detrimental for immigrants as they hamper access to the labor market. At the same time, the negative coefficients for the interaction terms of employment protection and union coverage with the unemployment rate indicate that if unemployment becomes large, insider-outsider effects may become an issue.

We also find a negative effect of the income tax wedge on migration decisions, although higher taxes are potentially connected with better public services. The negative effect of pension replacement rates can be explained by the fact that more generous pension systems usually involve higher contributions and, hence, create a higher "implicit tax" than less ambitious schemes. Also, they may be subject to higher political risks in countries with low fertility rates. Good health-care systems and good education systems involve higher taxes as well which have to be paid also by healthy or childless immigrants.

\footnotetext{
${ }^{22}$ Also, except for union coverage, median and average estimates reported in table 5 all have the same signs.
} 
Nevertheless, the quality of both systems has a positive effect on migration decisions. ${ }^{23}$ The negative effect of the share of high-skilled people in the destination country is a bit puzzling. However, a potential explanation is that quite a number of migrants are high-skilled themselves and have to compete against these "incumbents". We will discuss this in more detail below, based on additional estimations that are differentiated by skill levels of migrants. There, we also obtain more differentiated results regarding the effects of labor-market institutions.

To reduce the potential selection of our sample through re-migration, we repeat our estimations for the sub-group of individuals who migrated after 1995, i.e., within a maximum period of 10 years. The results are shown in table $6 .{ }^{24}$ By and large, the estimates confirm our earlier results, but three coefficients change their sign. We now find a positive effect of the pension replacement rate, while the estimates for union coverage and unemployment benefits become negative. The latter may indicate that insider-outsider problems arising from labor-market institutions are indeed relevant for newly arriving migrants. $^{25}$

To assess the quantitative importance of our estimates, we calculate a matrix of elasticities for the socio-economic and institutional variables that is presented in table $7 .{ }^{26}$ Among other things, we find that a $1 \%$ increase in the unemployment rate in the US decreases the probability to migrate to the US by $0.13 \%$, while it increases the one to go to Germany by $0.07 \%$, to the UK by $0.02 \%$ and to France by $0.04 \%$ (thus exactly absorbing the change in Prob(US)). A $1 \%$ increase in the unemployment rate in France decreases

\footnotetext{
${ }^{23}$ Higher quality of the health-care system is reflected in a decrease in infant mortality.

${ }^{24}$ In another series of alternative estimates, we also applied a different weighting scheme for individual observations, hypothetically normalizing the population in each of our destination countries to 50 million. The idea was to avoid any biases that might arise from huge differences in terms of population size. However, the results were basically unchanged.

${ }^{25}$ Alternatively, there could be both time effects and cohort effects affecting the results with respect to more recent immigration.

${ }^{26}$ Note that these elasticities do not reflect indirect effects of changes in institutions. For instance, an increase in unemployment benefits is often linked to a decrease in (net) wages. Our elasticities show how large the effects of institutions are in ceteris-paribus terms and give us an idea of the importance of these institutions for the choice of a destination country.
} 
the probability to go to France by $0.83 \%$ (the large difference between the US and France being due to the fact that a $1 \%$ increase equals a total change by 0.07 percentage points in the US, but by 0.19 percentage points in France). Also, the ex-ante probability to go to the US is higher than the probability to go to France. The elasticities with respect to wages have the same magnitude as those for unemployment rates, but with opposite signs. Most of the elasticities regarding the institutional variables are even larger than those for wages and unemployment rates. Note, however, that this is partly due to the scaling and the actual range of variation of the variables. ${ }^{27}$ In any case, they show that the role of labor-market institutions and other institutional characteristics of potential destination countries is not only statistically but also economically significant for migrants' location choices.

Determinants of location choices are very likely to differ for high-skilled and low-skilled migrants. Therefore, we further exploit out micro-data and repeat our estimates running separate regressions for low-skilled (ISCED 0-2) and qualified (ISCED 3-6) migrants. ${ }^{28}$ Note that, in contrast to existing studies based on macro data, we already control for differences between skill levels in the analysis of the full sample. However, the estimated coefficients only represent average effects, and skill-related differences are therefore captured in option-invariant variables and in the error term.

Table 8 summarizes the estimates for low-skilled and qualified migrants. Note that the estimates for qualified immigrants are in general more reliable than those for low-skilled ones: High-skilled persons are relatively free in their choice of a destination country, while low-skilled people face more restrictive immigration policies and thus a more limited choice of destinations. For wages, networks and employment protection we find positive effects for both groups, as in the full data set; for unemployment and tax wedges we find negative effects. The other estimates differ between the two groups. The estimated effects for

\footnotetext{
${ }^{27}$ For instance, the employment protection indicator effectively ranges from 0.7 to 2.9 , while the PISA scores lie between 489 and 516 points (cf. table 3).

${ }^{28}$ In this case, we exclude interactions with the unemployment rate, as they could lead to multicollinearity in this smaller data set.
} 
union coverage and unemployment benefits are positive for low-skilled immigrants and negative for the qualified. This could be explained by the fact that low-skilled people usually benefit more from high unemployment benefits and collectively negotiated wages than high-skilled ones. In fact, unemployment benefits are generally associated with costs which have to be paid more than proportionally by people with higher skills. Pension replacement rates now have a positive effect for high-skilled people, while for the low skilled the effect is still negative. The observed change for the high skilled might be due to the fact that the pension replacement rates as we use them, i.e. differentiated by wage brackets, indeed capture two characteristics of pension systems: their overall generosity as well as their tax-benefit link. There is evidence that both are positively connected (see Koethenbuerger et al. 2008); hence, the high skilled might be better off in countries with higher pension replacement rates which are less redistributive, whereas low-skilled immigrants might prefer systems that are less generous, but possibly more redistributive. PISA scores and the share of foreigners have the expected positive sign for high-skilled immigrants and a negative sign for the low skilled while infant mortality has the expected negative sign for the high skilled and a positive sign for low-skilled immigrants. ${ }^{29}$ For these specific results, even public expenditure does not offer a plausible reason, as the high skilled usually pay more taxes than the low skilled. Moreover, low-skilled immigrants tend to have more children and often suffer from more health problems than the high skilled. We consider these results as underlining the lower reliability of the estimates for the low skilled as just discussed. The share of high-skilled people shows the expected signs now. For high-skilled immigrants who have to compete with high-skilled natives, it is negative; for low-skilled immigrants who are probably complements, it is positive.

\footnotetext{
${ }^{29}$ In the case of low-skilled migrants, the negative sign for PISA scores and the positive effect of infant mortality, which captures a low quality of the health system, are puzzling.
} 


\section{Conclusions}

The decision to migrate to a particular country is a complex process and may be affected by various factors. Economists conventionally expect wages and unemployment rates to have an impact on this decision. In this paper, we show that the institutional setting in potential destination countries also plays an important role. Effectively, our results indicate that wages and unemployment rates alone do by far not suffice to explain location choices of ("non-refugee") migrants.

In addition to the conventional effects of wages and unemployment rates, which are positive respectively negative, we find a positive, but declining, effect of the size of immigrant networks and a positive effect of the "openness" of a country in general. For employment protection, union coverage and unemployment benefits, the effects turn out to be positive as well. Thus, protection against labor-market risks is obviously important for immigrants. ${ }^{30}$ At the same time, there are indications that insider-outsider problems related to these institutions become an issue if unemployment becomes large. In addition, a higher tax wedge has a negative effect, deterring potential migrants. We also find that PISA scores have a positive effect and infant mortality a negative effect on the migration decision, indicating that migrants value good education and health systems. Our estimate for pension benefits is negative, arguably because of the higher implicit tax rate and higher political risks associated with more generous pension schemes.

Our results regarding the effects of labor-market institutions become more differentiated if we restrict attention to migrants who arrived during the last 10 years only. Union coverage and unemployment benefits then have a negative impact, while employment protection still has a positive one. If we run separate estimations for migrants in different skill groups, the same is true with respect to migration of qualified individuals. Again,

\footnotetext{
${ }^{30} \mathrm{An}$ interesting issue that arises in this context is that of the risk aversion of migrants (see, e.g., Chiswick 1978; and Todaro 1980, for early contributions). Generally speaking migrants should be characterized by a low degree of risk aversion as they take on the risk of migrating. But this is no contradiction to our finding that they are seeking some protection. Also note that we neither compare their risk attitude to that of the population in the migrants' source countries nor to that of the natives of their destination countries.
} 
this may point to negative repercussions of labor-market institutions on the migrants' labor-market prospects.

We are unable to consider all the characteristics of destination countries that are potentially important for the migration decision. For instance, we are lacking any measures for the access of migrants to housing. ${ }^{31}$ Also, some of the proxies we are using, e.g., for education systems, health protection as well as immigration policies, have limitations resulting from the lack of consistent data. Another shortcoming of our analysis arises from the fact that, for some of the variables we include, there is actually little variation in the data. For some of the institutions we investigate, it is difficult to reconstruct all variation that exists at the individual level, while others are simply fixed at a national level, i.e., they are the same for all migrants living in one country. Still, combining micro-data from four major destination countries we provide new insights as to whether and how institutions play a role for migration decisions.

\section{References}

[1] Amemiya, Takeshi (1981), "Qualitative Response Models: A Survey", Journal of Economic Literature 19(4), 1483-1536 .

[2] Åslund, Olof (2005), "Now and forever? Initial and subsequent location choices of immigrants", Regional Science and Urban Economics 35, 141- 165.

[3] Baas, Timo and Herbert Brücker (2008), "Macroeconomic consequences of migration diversion - A CGE simulation for Germany and the UK", IAB Discussion Paper No. 03/2008, Nürnberg.

[4] Bartel, Ann P. (1989), "Where do the new US immigrants live?", Journal of Labour Economics $7(4), 371-391$.

[5] Bauer, Thomas K., Gil Epstein and Ira N. Gang (2005), "Enclaves, language and the location choice of immigrants", Journal of Population Economics 18(4), 649-662.

\footnotetext{
${ }^{31}$ Climate and natural beauty are also very likely to play a role for migration decisions. However, their effects can only be analyzed in a meaningful way at a regional, not at a national level.
} 
[6] Bauer, Thomas K., Gil Epstein and Ira N. Gang (2007), "The Influence of Stocks and Flows on Migrants' Location Choices", in Solomon W. Polachek und Olivier Bargain (Hrsg.), Aspects of Worker Well-Being, Research in Labor Economics 46, 199-229.

[7] Borjas, George J. (1999), "Immigration and Welfare Magnets", Journal of Labor Economics 17(4), $607-637$.

[8] British Council and Migration Policy Group (2007), Migration Integration Policy Index, Brussels.

[9] Cameron, A. Colin and Pravin K. Trivedi (2005), Microeconometrics: Methods and Applications, Cambridge University Press, New York.

[10] Chiswick, Barry R. (1978), "The Effect of Americanization on the Earnings of Foreign-born Men", Journal of Political Economy 86(5), 897-921.

[11] Constant, Amelie F. and Elena D'Agosto (2008), "Where Do the Brainy Italians Go?", IZA Discussion Paper No. 3325, Bonn.

[12] Defoort, Cécily (2006), "Tendances de long terme des migrations internationales: Analyse à partir des 6 principaux pays receveurs", mimeo.

[13] Docquier, Frédéric, Oliver Lohest and Abdesalam Marfouk (2008), "What determines migrants' destination choice?", mimeo.

[14] Geis, Wido, Silke Uebelmesser and Martin Werding (2008), "Why go to France or Germany, if you could as well go to the UK or the US? Selective Features of Immigration to Four Major OECD Countries ", CESifo Working Paper No. 2427, Munich.

[15] Harris, John R. and Michael P. Todaro (1969), "Migration, Unemployment and Development: A Two Sector Analysis", American Economic Review 60(1), 126-142.

[16] Hegre, Håvard and Nicholas Sambanis (2006), "Sensitivity Analysis of Empirical Results on Civil War Onset", Journal of Conflict Resolution 50(4), 508-535.

[17] Institute for Education Sciences (2007), Comparative Indicators of Education in the United States and Other G-8 Countries: 2006, National Center for Education statistics, Washington. 
[18] Jaeger, David A. (2000): "Local labor markets, admission categories and immigrant location choice", Working Paper, Department of Economics, Hunter College, NY.

[19] Koethenbuerger, Marko, Panu Poutvaara and Paola Profeta (2008), "Why are more redistributive social security systems smaller? A median voter approach", Oxford Economic Papers 60(2), 275292.

[20] Koller, Barbara (1997); "Aussiedler der großen Zuwanderungswellen - was ist aus ihnen geworden? Die Eingliederungssituation von Aussiedlerinnen und Aussiedlern auf dem Arbeitsmarkt in Deutschland", Mitteilungen aus der Arbeitsmarkt- und Berufsforschung 30(4), 766-789.

[21] Leamer, Edward E. (1985), "Sensitivity Analyses Would Help", American Economic Review 75(3), 308-313.

[22] Lundborg, Per (1993), "Determinants of Migration in the Nordic Labor Market", Scandinavian Journal of Economics 93(3), 363-375.

[23] Mayda, Anna-Maria (2007), "International migration: A panel data analysis of the determinants of bilateral flows", Centre for Research and Analysis of Migration, CReAM discussion paper No. 07/07, London.

[24] Munshi, Kavian (2003), "Networks in the Modern Economy: Mexican Migrants in the U.S. Labor Market", Quarterly Journal of Economics 118(2), 549-599.

[25] OECD (2004), Employment Outlook: 2004 Edition, Paris.

[26] OECD (2006a), PISA 2006: Science Competencies for Tomorrow's World, Paris.

[27] OECD (2006b), Taxing Wages 2005-2006, Paris.

[28] OECD (2007a), OECD in Figures: 2007 Edition, Paris.

[29] OECD (2007b), Health at a Glance: 2007 Edition, Paris.

[30] OECD (2007c), Pensions at a Glance: 2007 Edition, Paris.

[31] Office for National Statistics (2007), LFS User Guide - Volume 9: EuroStat \&5 EuroStat Derived Variables, Newport. 
[32] Office for National Statistics (2000), Standard Occupational Classification 2000, Newport.

[33] Office for National Statistics, Social and Vital Statistics Division and Northern Ireland Statistics and Research Agency, Central Survey Unit (2005), Quarterly Labour Force Survey, March - May 2005 [computer file], Colchester, Essex [distributor: UK Data Archive, SN: 5211].

[34] Pedersen, Peder J., Mariola Pytlikova and Nina Smith (2008), "Selection or Network Effects? Migration Flows into 27 OECD Countries, 1990-2000", European Economic Review 52(7), 1160-1186.

[35] Sala-i-Martin, Xavier X. (1997), "I Just Ran Two Million Regressions", American Economic Review 87(2), Papers and Proceedings, 178-183.

[36] Sjaastad, Larry A. (1962), "The Costs and Returns on Human Migration", Journal of Political Economy 70, 80-93.

[37] Schroedter, Julia H., Yvonne Lechert and Paul Lüttinger (2006), "Die Umsetzung der Bildungsskala ISCED-1997 für die Volkszählung 1970, die Mikrozensus- Zusatzerhebung 1971 und die Mikrozensen 1976-2004", ZUMA-Methodenbericht No. 2006/08, Mannheim.

[38] Ruggles, Steven, Matthew Sobek, Trent Alexander, Catherine A. Fitch, Ronald Goeken, Patricia Kelly Hall, Miriam King, and Chad Ronnander (2004), Integrated Public Use Microdata Series: Version 3.0 [Machine-readable database], Minnesota Population Center, Minneapolis, MN.

[39] Todaro, Michael P. (1970), "A Model of Labor Migration and Unemployment in Less Developed Countries", American Economic Review 59(1), 138-148.

[40] Todaro, Michael P. (1980), "Internal Migration in Developing Countries: A Survey", in Richard A. Easterlin (ed.), Population and Economic Change in Developing Countries, University of Chicago Press, London and Chicago, 361- 402.

[41] Werding, Martin and Sonja Munz (2005), "Public pensions and international migration: some clarifications and illustrative results", Journal of Pension Economics and Finance 4(1), 181-207. 


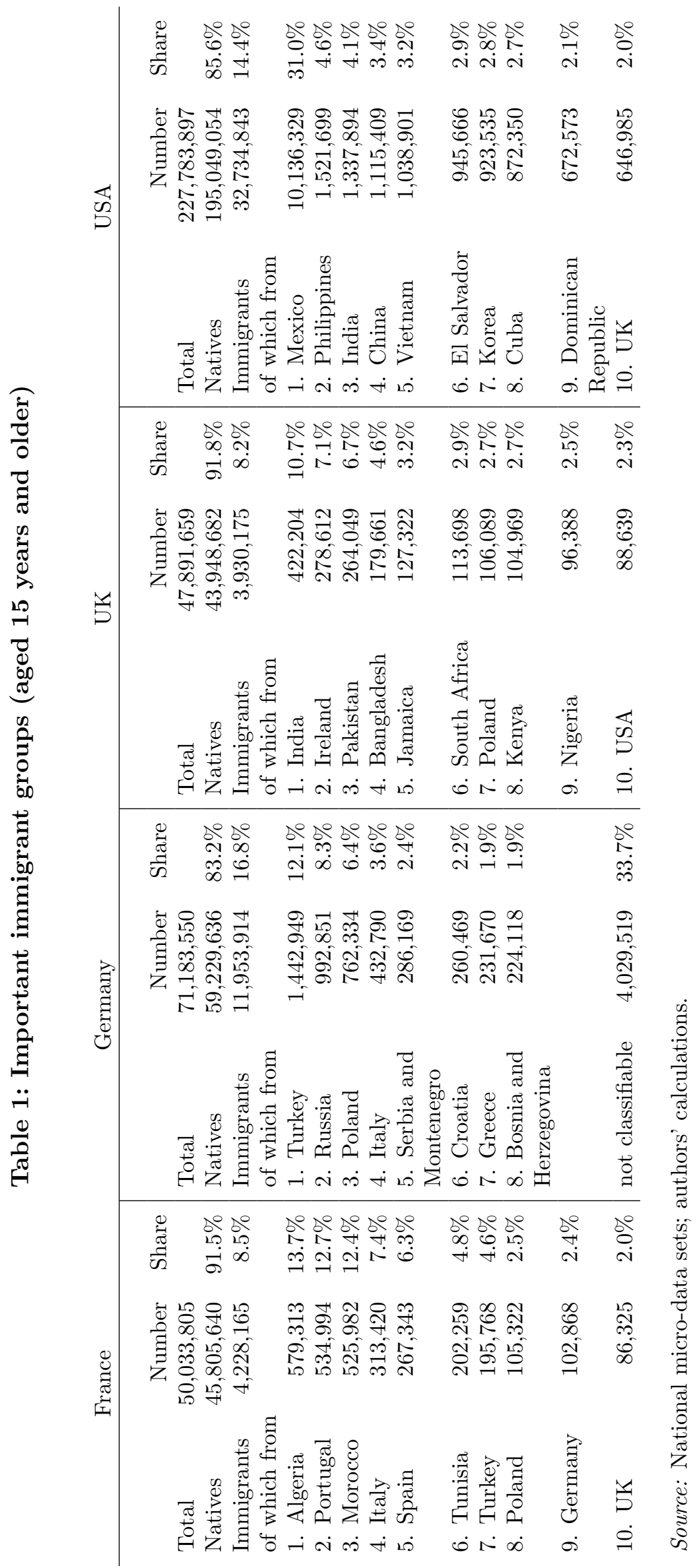


Table 2: Educational attainments of immigrants (aged 25-54)

\begin{tabular}{|c|c|c|c|c|}
\hline Immigrants & France & Germany & UK & USA \\
\hline \multicolumn{5}{|l|}{ ISCED 0-1 } \\
\hline Number & 699,323 & 718,828 & 509,257 & $3,884,751$ \\
\hline Share & $28.56 \%$ & $11.70 \%$ & $21.13 \%$ & $18.27 \%$ \\
\hline Participation rate & $67.98 \%$ & $60.36 \%$ & $49.95 \%$ & $73.25 \%$ \\
\hline Unemployment rate & $19.15 \%$ & $26.86 \%$ & $9.25 \%$ & $7.99 \%$ \\
\hline Wage* & $\$ 12.91$ & $\$ 13.51$ & $\$ 12.47$ & $\$ 11.39$ \\
\hline \multicolumn{5}{|l|}{ ISCED 2} \\
\hline Number & 512,363 & $1,596,041$ & 305,096 & $2,659,406$ \\
\hline Share & $20.92 \%$ & $25.97 \%$ & $12.66 \%$ & $12.51 \%$ \\
\hline Participation rate & $76.05 \%$ & $75.08 \%$ & $78.99 \%$ & $74.26 \%$ \\
\hline Unemployment rate & $21.55 \%$ & $20.65 \%$ & $7.65 \%$ & $7.80 \%$ \\
\hline Wage* & $\$ 13.22$ & $\$ 13.42$ & $\$ 15.98$ & $\$ 12.84$ \\
\hline \multicolumn{5}{|l|}{ ISCED $3+4$} \\
\hline Number & 701,190 & $2,547,618$ & 880,387 & $7,583,786$ \\
\hline Share & $28.63 \%$ & $41.46 \%$ & $36.53 \%$ & $35.67 \%$ \\
\hline Participation rate & $81.39 \%$ & $84.46 \%$ & $84.08 \%$ & $78.40 \%$ \\
\hline Unemployment rate & $17.19 \%$ & $15.56 \%$ & $5.65 \%$ & $6.26 \%$ \\
\hline Wage* & $\$ 14.23$ & $\$ 14.71$ & $\$ 19.77$ & $\$ 16.38$ \\
\hline \multicolumn{5}{|l|}{ ISCED $5+6$} \\
\hline Number & 535,926 & $1,282,602$ & 715,139 & $7,132,580$ \\
\hline Share & $21.89 \%$ & $20.87 \%$ & $29.68 \%$ & $33.55 \%$ \\
\hline Participation rate & $80.90 \%$ & $81.55 \%$ & $87.75 \%$ & $81.23 \%$ \\
\hline Unemployment rate & $15.81 \%$ & $12.69 \%$ & $5.43 \%$ & $4.24 \%$ \\
\hline Wage* & $\$ 19.56$ & $\$ 20.02$ & $\$ 26.16$ & $\$ 30.08$ \\
\hline
\end{tabular}

\begin{tabular}{|c|c|c|c|c|}
\hline Natives & France & Germany & UK & USA \\
\hline \multicolumn{5}{|l|}{ ISCED 0-1 } \\
\hline Number & $1,613,090$ & 368,143 & $2,590,481$ & $1,667,184$ \\
\hline Share & $7.13 \%$ & $1.24 \%$ & $11.96 \%$ & $1.63 \%$ \\
\hline Participation rate & $74.75 \%$ & $68.14 \%$ & $61.94 \%$ & $51.41 \%$ \\
\hline Unemployment rate & $13.18 \%$ & $29.47 \%$ & $6.98 \%$ & $13.33 \%$ \\
\hline Wage* & $\$ 12.87$ & $\$ 9.61$ & $\$ 14.17$ & $\$ 14.24$ \\
\hline \multicolumn{5}{|l|}{ ISCED 2} \\
\hline Number & $4,478,207$ & $3,003,786$ & $3,905,006$ & $7,655,447$ \\
\hline Share & $19.78 \%$ & $10.14 \%$ & $18.03 \%$ & $7.47 \%$ \\
\hline Participation rate & $84.92 \%$ & $79.40 \%$ & $82.30 \%$ & $67.58 \%$ \\
\hline Unemployment rate & $12.10 \%$ & $18.42 \%$ & $4.27 \%$ & $14.63 \%$ \\
\hline Wage* & $\$ 14.44$ & $\$ 13.31$ & $\$ 15.99$ & $\$ 14.13$ \\
\hline \multicolumn{5}{|l|}{ ISCED $3+4$} \\
\hline Number & $10,167,941$ & $17,763,323$ & $8,428,241$ & $53,448,746$ \\
\hline Share & $44.92 \%$ & $59.96 \%$ & $38.91 \%$ & $52.18 \%$ \\
\hline Participation rate & $90.00 \%$ & $88.62 \%$ & $88.44 \%$ & $81.64 \%$ \\
\hline Unemployment rate & $6.90 \%$ & $9.87 \%$ & $2.78 \%$ & $6.39 \%$ \\
\hline Wage* & $\$ 15.32$ & $\$ 15.30$ & $\$ 18.60$ & $\$ 18.75$ \\
\hline \multicolumn{5}{|l|}{ ISCED $5+6$} \\
\hline Number & $6,375,285$ & $8,490,608$ & $6,736,941$ & $39,661,288$ \\
\hline Share & $28.17 \%$ & $28.66 \%$ & $31.10 \%$ & $38.72 \%$ \\
\hline Participation rate & $91.67 \%$ & $90.61 \%$ & $93.08 \%$ & $87.84 \%$ \\
\hline Unemployment rate & $5.45 \%$ & $3.92 \%$ & $1.81 \%$ & $3.01 \%$ \\
\hline Wage* & $\$ 20.86$ & $\$ 20.87$ & $\$ 25.87$ & $\$ 30.68$ \\
\hline
\end{tabular}




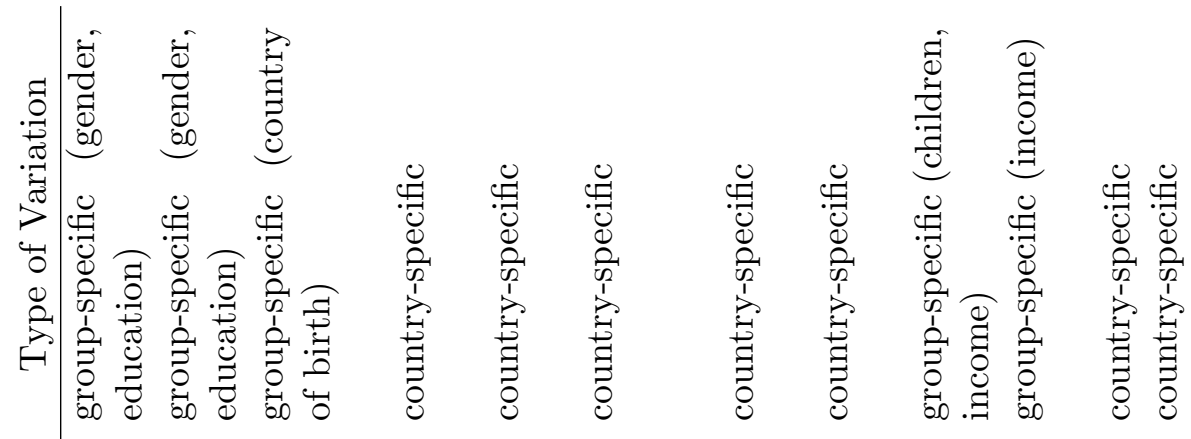

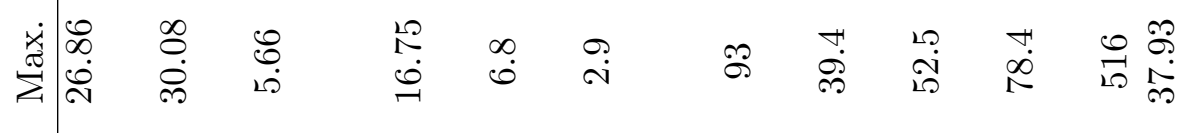

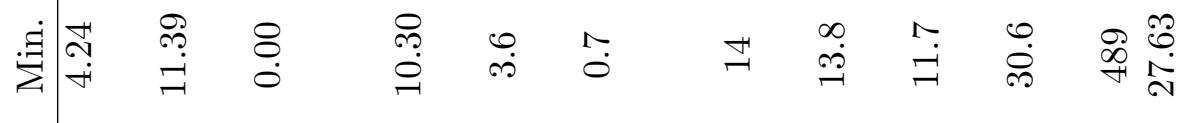

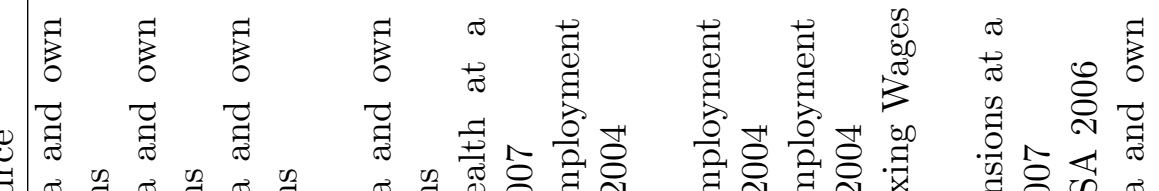

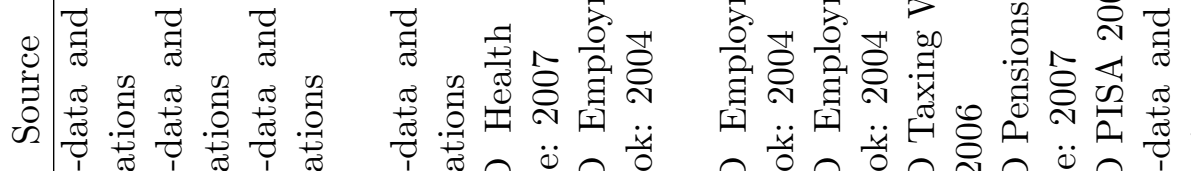

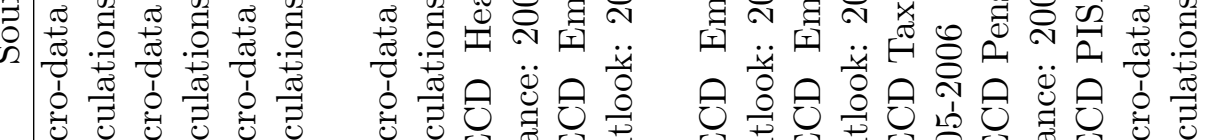

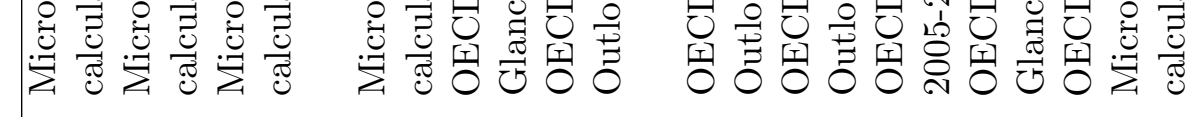

चี

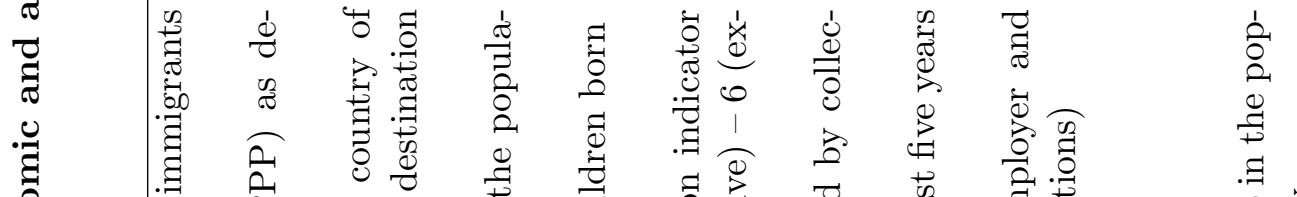

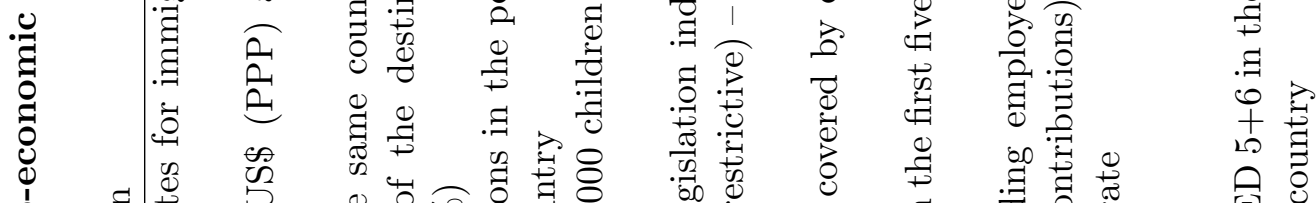

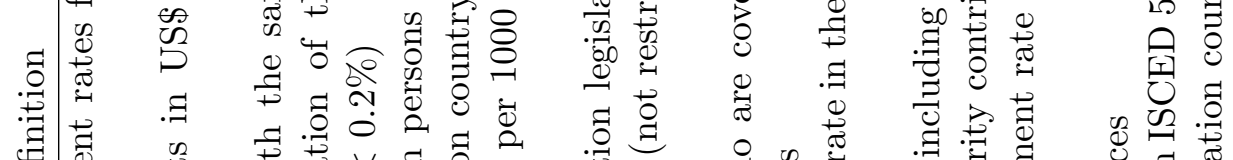

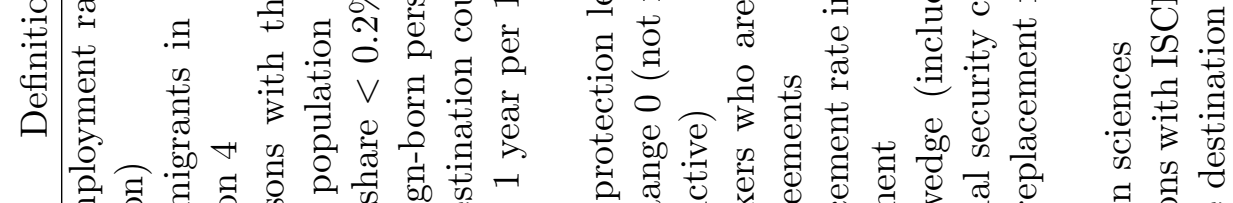

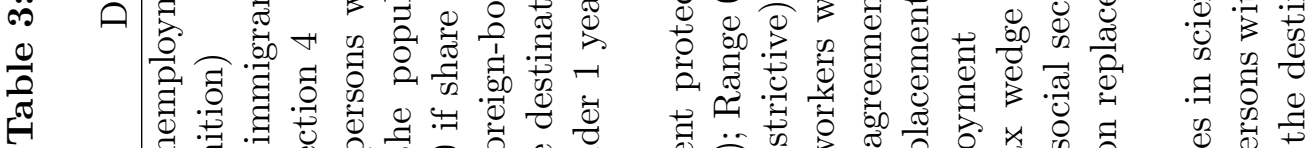

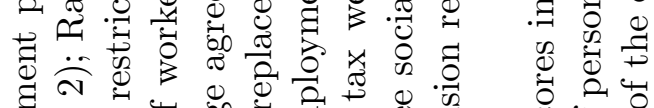

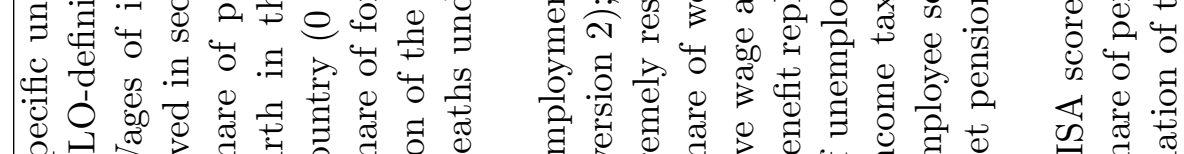

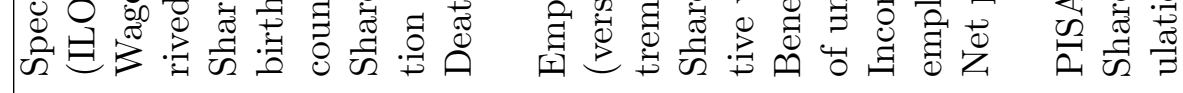

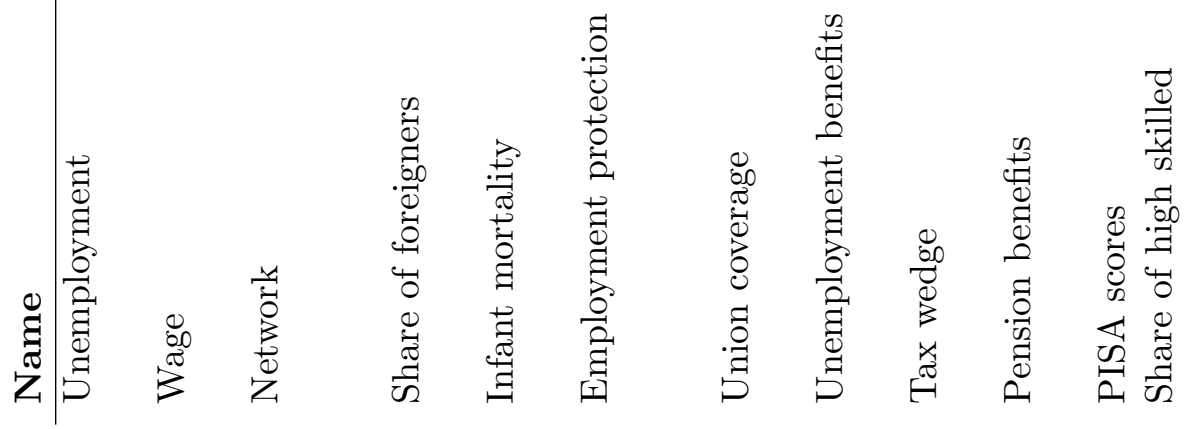




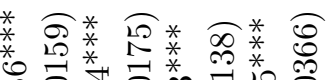

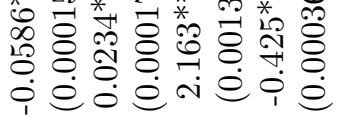

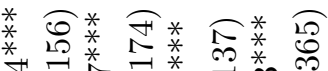

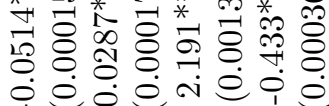

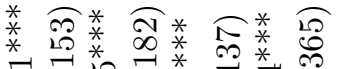

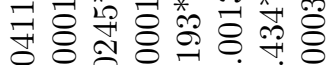

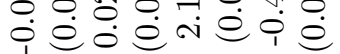

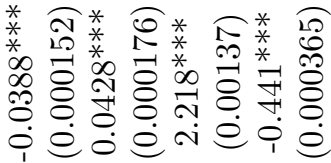

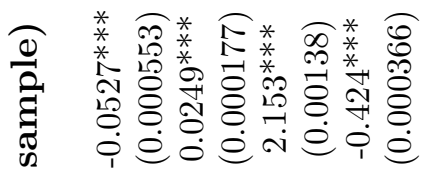

言

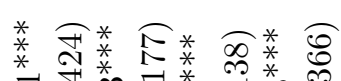

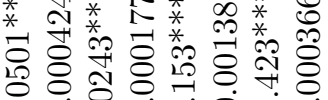

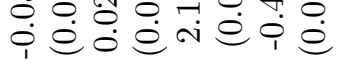

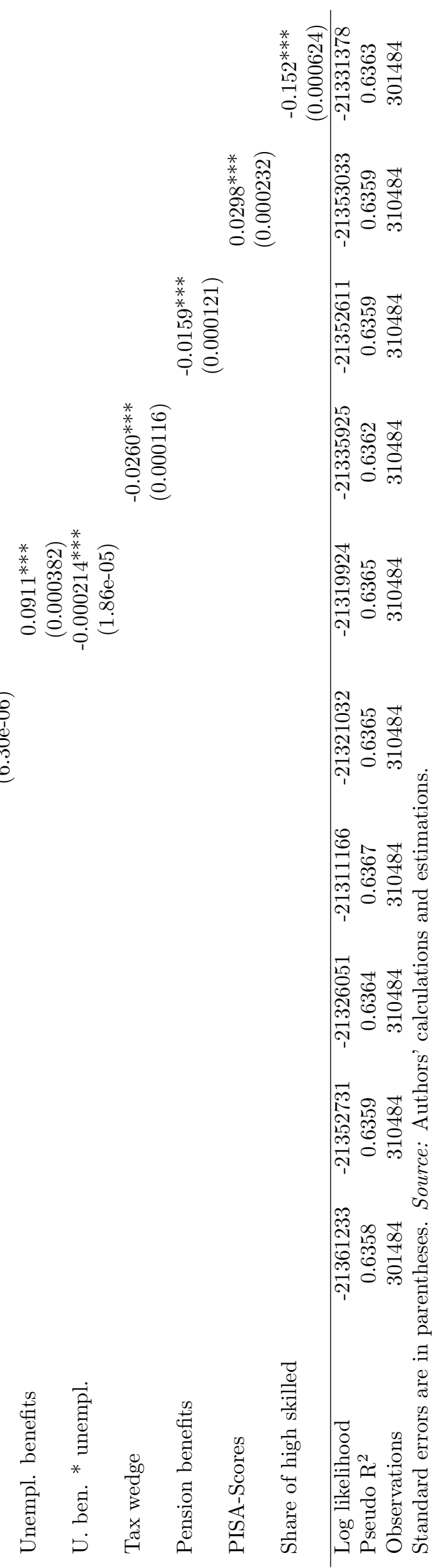




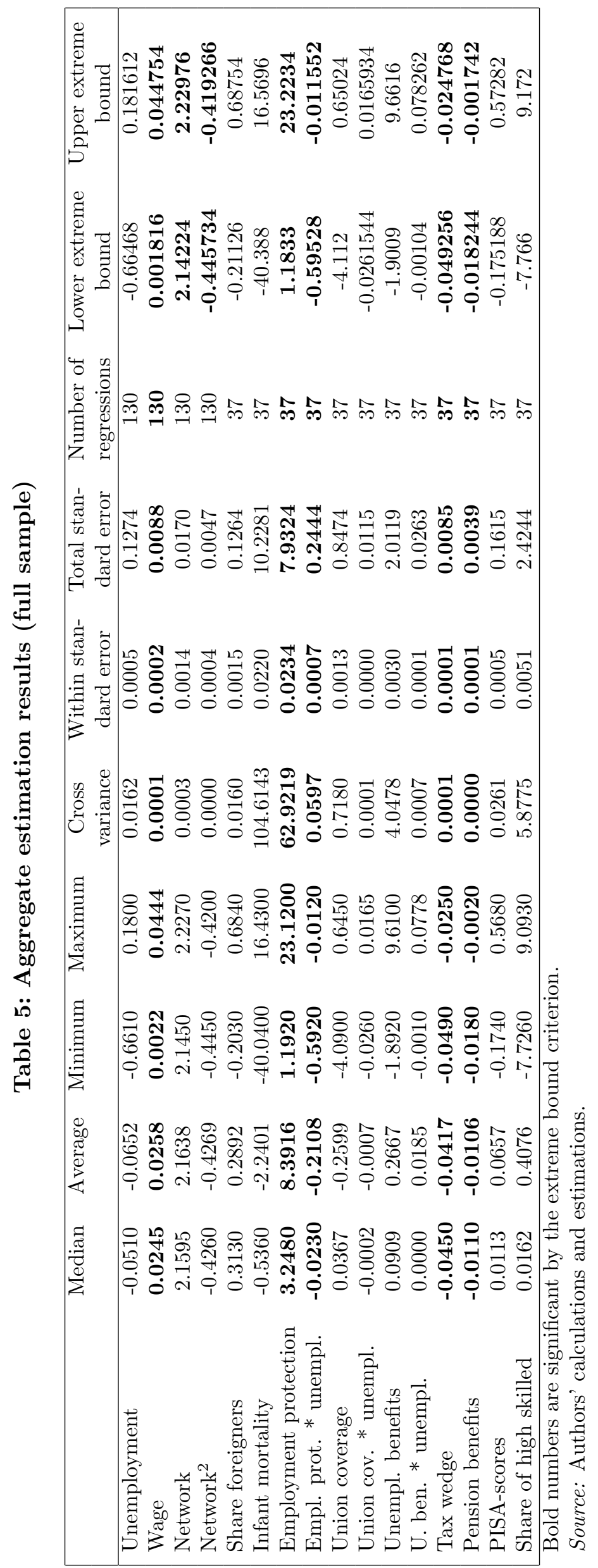




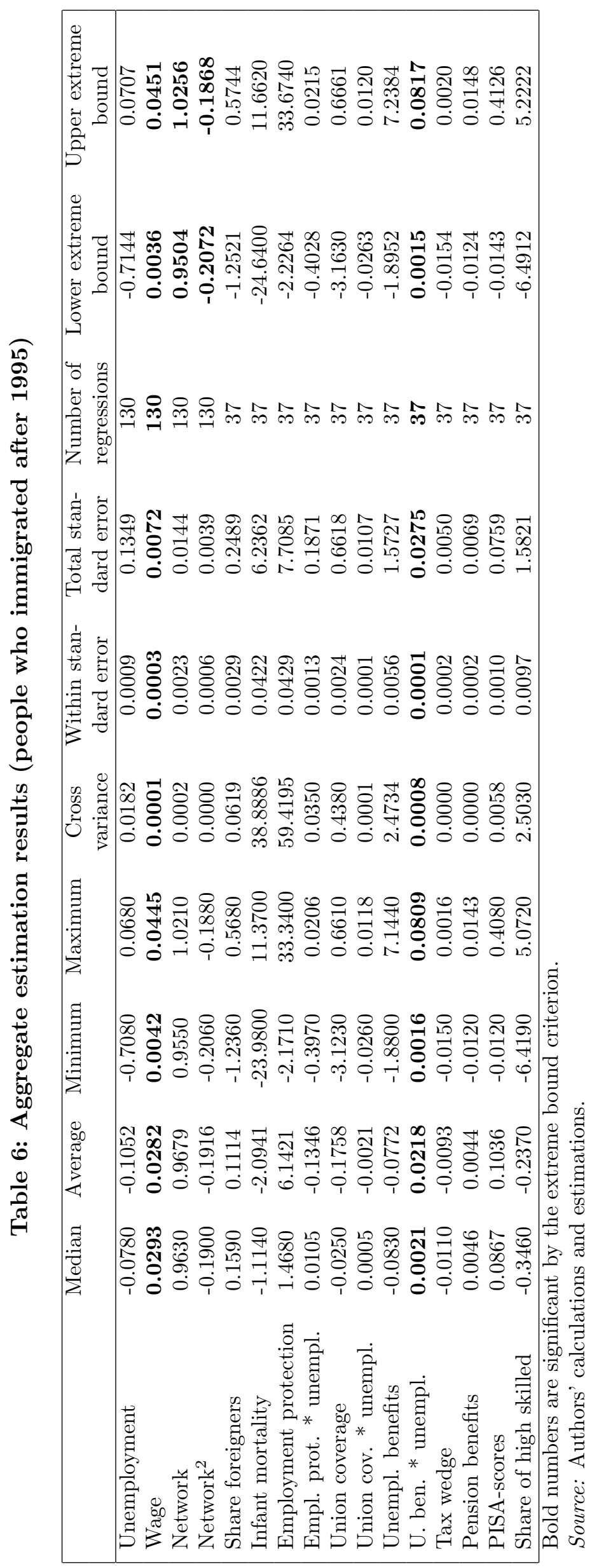


Table 7: Median elasticities (full sample)

\begin{tabular}{|c|c|c|c|c|c|c|}
\hline \multirow{5}{*}{$\begin{array}{l}1 \% \text { increase in } \\
\text { unemployment } \\
\text { rate in }\end{array}$} & & $\begin{array}{l}\text { Change in } \\
\text { Prob(US) }\end{array}$ & $\begin{array}{l}\text { Change in } \\
\text { Prob(GE) }\end{array}$ & $\begin{array}{l}\text { Change in } \\
\text { Prob(UK) }\end{array}$ & $\begin{array}{l}\text { Change in } \\
\text { Prob(FR) }\end{array}$ & $\begin{array}{c}\text { Average } \\
\text { value }\end{array}$ \\
\hline & US & -0.131 & 0.075 & 0.022 & 0.034 & $6.92 \%$ \\
\hline & Germany & 0.551 & -0.694 & 0.056 & 0.087 & $17.59 \%$ \\
\hline & UK & 0.207 & 0.069 & -0.307 & 0.031 & $6.64 \%$ \\
\hline & France & 0.575 & 0.199 & 0.057 & -0.831 & $18.50 \%$ \\
\hline \multirow{5}{*}{$\begin{array}{l}1 \% \text { increase in } \\
\text { wage per hour in }\end{array}$} & & $\begin{array}{l}\text { Change in } \\
\text { Prob(US) }\end{array}$ & $\begin{array}{l}\text { Change in } \\
\text { Prob(GE) }\end{array}$ & $\begin{array}{l}\text { Change in } \\
\text { Prob(UK) }\end{array}$ & $\begin{array}{l}\text { Change in } \\
\text { Prob(FR) }\end{array}$ & $\begin{array}{l}\text { Average } \\
\text { value }\end{array}$ \\
\hline & US & 0.150 & -0.089 & -0.029 & -0.032 & $\$ 19.18$ \\
\hline & Germany & -0.237 & 0.288 & -0.023 & -0.029 & $\$ 15.34$ \\
\hline & UK & -0.310 & -0.098 & 0.445 & -0.036 & $\$ 20.21$ \\
\hline & France & -0.239 & -0.075 & -0.023 & 0.337 & $\$ 15.25$ \\
\hline \multirow{5}{*}{$\begin{array}{l}1 \% \text { increase in } \\
\text { Network in }\end{array}$} & & $\begin{array}{l}\text { Change in } \\
\text { Prob(US) }\end{array}$ & $\begin{array}{l}\text { Change in } \\
\text { Prob(GE) }\end{array}$ & $\begin{array}{l}\text { Change in } \\
\text { Prob(UK) }\end{array}$ & $\begin{array}{l}\text { Change in } \\
\text { Prob(FR) }\end{array}$ & $\begin{array}{l}\text { Average } \\
\text { value }\end{array}$ \\
\hline & US & 0.015 & -0.004 & -0.008 & -0.003 & $0.90 \%$ \\
\hline & Germany & -0.026 & 0.052 & -0.005 & -0.021 & $0.55 \%$ \\
\hline & UK & -0.076 & -0.011 & 0.093 & -0.006 & $0.06 \%$ \\
\hline & France & -0.028 & -0.045 & -0.012 & 0.085 & $0.11 \%$ \\
\hline \multirow{5}{*}{$\begin{array}{l}1 \% \text { increase in } \\
\text { share of foreign } \\
\text { born in }\end{array}$} & & $\begin{array}{l}\text { Change in } \\
\text { Prob(US) }\end{array}$ & $\begin{array}{l}\text { Change in } \\
\text { Prob(GE) }\end{array}$ & $\begin{array}{l}\text { Change in } \\
\text { Prob(UK) }\end{array}$ & $\begin{array}{l}\text { Change in } \\
\text { Prob(FR) }\end{array}$ & $\begin{array}{l}\text { Average } \\
\text { value }\end{array}$ \\
\hline & US & 1.676 & -0.982 & -0.294 & -0.400 & $15.46 \%$ \\
\hline & Germany & -3.231 & 3.983 & -0.319 & -0.433 & $16.75 \%$ \\
\hline & UK & -1.987 & -0.654 & 2.908 & -0.266 & $10.30 \%$ \\
\hline & France & -2.251 & -0.741 & -0.222 & 3.214 & $11.67 \%$ \\
\hline \multirow{6}{*}{$\begin{array}{l}1 \% \text { increase in } \\
\text { infant mortality }\end{array}$} & & Change in & Change in & Change in & Change in & Average \\
\hline & & Prob(US) & Prob(GE) & Prob(UK) & Prob(FR) & value \\
\hline & US & -1.261 & 0.737 & 0.223 & 0.301 & 6.8 \\
\hline & Germany & 1.286 & -1.587 & 0.128 & 0.173 & 3.9 \\
\hline & UK & 1.682 & 0.553 & -2.460 & 0.226 & 5.1 \\
\hline & France & 1.187 & 0.390 & 0.118 & -1.695 & 3.6 \\
\hline \multirow{5}{*}{$\begin{array}{l}1 \% \text { increase in } \\
\text { employment } \\
\text { protection } \\
\text { indicator in }\end{array}$} & & $\begin{array}{l}\text { Change in } \\
\text { Prob(US) }\end{array}$ & $\begin{array}{l}\text { Change in } \\
\text { Prob(GE) }\end{array}$ & $\begin{array}{l}\text { Change in } \\
\text { Prob(UK) }\end{array}$ & $\begin{array}{l}\text { Change in } \\
\text { Prob(FR) }\end{array}$ & $\begin{array}{l}\text { Average } \\
\text { value }\end{array}$ \\
\hline & US & 0.786 & -0.460 & -0.138 & -0.189 & 0.7 \\
\hline & Germany & -4.999 & 6.166 & -0.494 & -0.673 & 2.5 \\
\hline & UK & -2.199 & -0.722 & 3.218 & -0.296 & 1.1 \\
\hline & France & -5.799 & -1.904 & -0.573 & 8.275 & 2.9 \\
\hline
\end{tabular}


Table 7 (continued)

\begin{tabular}{|c|c|c|c|c|c|c|}
\hline \multirow{5}{*}{$\begin{array}{l}1 \% \text { increase in } \\
\text { union coverage in }\end{array}$} & & & Prob(GE) & & ) & \\
\hline & US & 0.178 & -0.104 & -0.031 & -0.042 & $14 \%$ \\
\hline & Germany & -1.537 & 1.894 & -0.151 & -0.206 & $68 \%$ \\
\hline & UK & -0.746 & -0.245 & 1.091 & -0.100 & $33 \%$ \\
\hline & France & -2.102 & -0.692 & -0.207 & 3.000 & $93 \%$ \\
\hline \multirow{5}{*}{$\begin{array}{l}1 \% \text { increase in } \\
\text { unemployment } \\
\text { benefits in }\end{array}$} & & $\begin{array}{l}\text { Change in } \\
\text { Prob(US) }\end{array}$ & $\begin{array}{l}\text { Change in } \\
\operatorname{Prob}(\mathrm{GE})\end{array}$ & $\begin{array}{l}\text { Change in } \\
\text { Prob(UK) }\end{array}$ & $\begin{array}{l}\text { Change in } \\
\text { Prob(FR) }\end{array}$ & $\begin{array}{l}\text { Average } \\
\text { value }\end{array}$ \\
\hline & US & 0.434 & -0.254 & -0.077 & -0.104 & $13.8 \%$ \\
\hline & Germany & -1.634 & 2.016 & -0.162 & -0.220 & $29.2 \%$ \\
\hline & UK & -0.912 & -0.300 & 1.334 & -0.123 & $16.3 \%$ \\
\hline & France & -2.204 & -0.724 & -0.219 & 3.148 & $39.4 \%$ \\
\hline \multirow{5}{*}{$\begin{array}{l}1 \% \text { increase in } \\
\text { tax wedge in }\end{array}$} & & Change in & Change in & Change in & Change in & Average \\
\hline & US & S) & $\mathrm{XE)}$ & JK) & FR) & $\begin{array}{c}\text { value } \\
22.17 \%\end{array}$ \\
\hline & Germany & 1.274 & -1.582 & 0.129 & 0.179 & $45.73 \%$ \\
\hline & UK & 0.875 & 0.291 & -1.285 & 0.118 & $31.23 \%$ \\
\hline & France & 1.314 & 0.435 & 0.131 & -1.880 & $46.77 \%$ \\
\hline \multirow{6}{*}{$\begin{array}{l}1 \% \text { increase in } \\
\text { pension benefits in }\end{array}$} & & Change in & Change in & Change in & Change in & Average \\
\hline & & Prob(US) & Prob(GE) & Prob(UK) & Prob(FR) & value \\
\hline & US & -0.243 & 0.140 & 0.042 & 0.060 & $58.6 \%$ \\
\hline & Germany & 0.414 & -0.511 & 0.041 & 0.055 & $57.3 \%$ \\
\hline & UK & 0.328 & 0.108 & -0.485 & 0.048 & $45.7 \%$ \\
\hline & France & 0.461 & 0.152 & 0.046 & -0.659 & $63.9 \%$ \\
\hline \multirow{6}{*}{$\begin{array}{l}1 \% \text { increase in } \\
\text { PISA-score in }\end{array}$} & & Change in & Change in & Change in & Change in & Average \\
\hline & & Prob(Us & Prob(GE) & Prob(UK) & Prob(FR) & value \\
\hline & US & 1.911 & -1.117 & -0.338 & -0.457 & 489 \\
\hline & Germany & -3.587 & 4.425 & -0.356 & -0.483 & 516 \\
\hline & UK & -3.580 & -1.176 & 5.237 & -0.482 & 515 \\
\hline & France & -3.441 & -1.130 & -0.342 & 4.913 & 495 \\
\hline \multirow{5}{*}{$\begin{array}{l}1 \% \text { increase in } \\
\text { share of high skilled } \\
\text { persons (ISCED } 5+6 \text { ) } \\
\text { in }\end{array}$} & & $\begin{array}{l}\text { Change in } \\
\text { Prob(US) }\end{array}$ & $\begin{array}{l}\text { Change in } \\
\text { Prob(GE) }\end{array}$ & $\begin{array}{l}\text { Change in } \\
\text { Prob(UK) }\end{array}$ & $\begin{array}{l}\text { Change in } \\
\text { Prob(FR) }\end{array}$ & $\begin{array}{l}\text { Average } \\
\text { value }\end{array}$ \\
\hline & US & 0.213 & -0.125 & -0.037 & -0.051 & $37.93 \%$ \\
\hline & Germany & -0.276 & 0.340 & -0.027 & -0.037 & $27.63 \%$ \\
\hline & UK & -0.306 & -0.101 & 0.448 & -0.041 & $30.70 \%$ \\
\hline & France & -0.276 & -0.091 & -0.027 & 0.394 & $27.68 \%$ \\
\hline
\end{tabular}

Change in Change in Change in Change in Average Prob(US) Prob(GE) Prob(UK) Prob(FR) value

Source: Authors' calculations and estimations. 


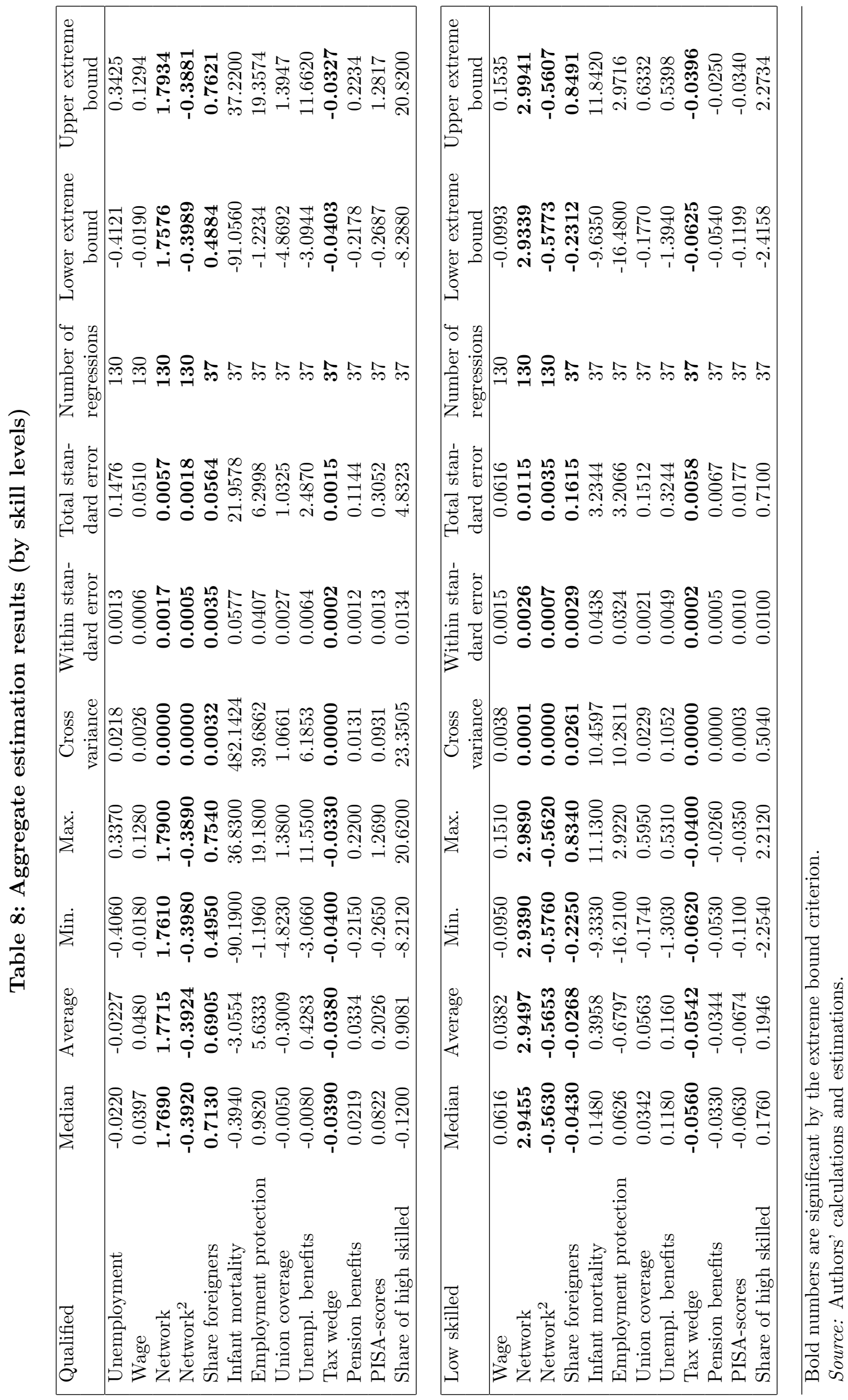




\section{CESifo Working Paper Series}

for full list see www.cesifo-group.org/wp

(address: Poschingerstr. 5, 81679 Munich, Germany, office@cesifo.de)

2441 Marcelo Resende, Concentration and Market Size: Lower Bound Estimates for the Brazilian Industry, October 2008

2442 Giandomenico Piluso and Roberto Ricciuti, Fiscal Policy and the Banking System in Italy. Have Taxes, Public Spending and Banks been Procyclical in the Long-Run? October 2008

2443 Bruno S. Frey and Katja Rost, Do Rankings Reflect Research Quality?, October 2008

2444 Guglielmo Maria Caporale, Antoaneta Serguieva and Hao Wu, Financial Contagion: Evolutionary Optimisation of a Multinational Agent-Based Model, October 2008

2445 Valentina Bosetti, Carlo Carraro and Massimo Tavoni, Delayed Participation of Developing Countries to Climate Agreements: Should Action in the EU and US be Postponed?, October 2008

2446 Alexander Kovalenkov and Xavier Vives, Competitive Rational Expectations Equilibria without Apology, November 2008

2447 Thiess Buettner and Fédéric Holm-Hadulla, Cities in Fiscal Equalization, November 2008

2448 Harry H. Kelejian and Ingmar R. Prucha, Specification and Estimation of Spatial Autoregressive Models with Autoregressive and Heteroskedastic Disturbances, November 2008

2449 Jan Bouckaert, Hans Degryse and Thomas Provoost, Enhancing Market Power by Reducing Switching Costs, November 2008

2450 Frank Heinemann, Escaping from a Combination of Liquidity Trap and Credit Crunch, November 2008

2451 Dan Anderberg, Optimal Policy and the Risk Properties of Human Capital Reconsidered, November 2008

2452 Christian Keuschnigg and Evelyn Ribi, Outsourcing, Unemployment and Welfare Policy, November 2008

2453 Bernd Theilen, Market Competition and Lower Tier Incentives, November 2008

2454 Ondřej Schneider, Voting in the European Union - Central Europe's Lost Voice, November 2008

2455 Oliver Lorz and Gerald Willmann, Enlargement versus Deepening: The Trade-off Facing Economic Unions, November 2008 
2456 Alfons J. Weichenrieder and Helen Windischbauer, Thin-Capitalization Rules and Company Responses, Experience from German Legislation, November 2008

2457 Andreas Knabe and Steffen Rätzel, Scarring or Scaring? The Psychological Impact of Past Unemployment and Future Unemployment Risk, November 2008

2458 John Whalley and Sean Walsh, Bringing the Copenhagen Global Climate Change Negotiations to Conclusion, November 2008

2459 Daniel Mejía, The War on Illegal Drugs in Producer and Consumer Countries: A Simple Analytical Framework, November 2008

2460 Carola Frydman, Learning from the Past: Trends in Executive Compensation over the Twentieth Century, November 2008

2461 Wolfgang Ochel, The Political Economy of Two-tier Reforms of Employment Protection in Europe, November 2008

2462 Peter Egger and Doina Maria Radulescu, The Influence of Labor Taxes on the Migration of Skilled Workers, November 2008

2463 Oliver Falck, Stephan Heblich and Stefan Kipar, The Extension of Clusters: Differencein-Differences Evidence from the Bavarian State-Wide Cluster Policy, November 2008

2464 Lei Yang and Keith E. Maskus, Intellectual Property Rights, Technology Transfer and Exports in Developing Countries, November 2008

2465 Claudia M. Buch, The Great Risk Shift? Income Volatility in an International Perspective, November 2008

2466 Walter H. Fisher and Ben J. Heijdra, Growth and the Ageing Joneses, November 2008

2467 Louis Eeckhoudt, Harris Schlesinger and Ilia Tsetlin, Apportioning of Risks via Stochastic Dominance, November 2008

2468 Elin Halvorsen and Thor O. Thoresen, Parents' Desire to Make Equal Inter Vivos Transfers, November 2008

2469 Anna Montén and Marcel Thum, Ageing Municipalities, Gerontocracy and Fiscal Competition, November 2008

2470 Volker Meier and Matthias Wrede, Reducing the Excess Burden of Subsidizing the Stork: Joint Taxation, Individual Taxation, and Family Splitting, November 2008

2471 Gunther Schnabl and Christina Ziegler, Exchange Rate Regime and Wage Determination in Central and Eastern Europe, November 2008

2472 Kjell Erik Lommerud and Odd Rune Straume, Employment Protection versus Flexicurity: On Technology Adoption in Unionised Firms, November 2008 
2473 Lukas Menkhoff, High-Frequency Analysis of Foreign Exchange Interventions: What do we learn?, November 2008

2474 Steven Poelhekke and Frederick van der Ploeg, Growth, Foreign Direct Investment and Urban Concentrations: Unbundling Spatial Lags, November 2008

2475 Helge Berger and Volker Nitsch, Gotcha! A Profile of Smuggling in International Trade, November 2008

2476 Robert Dur and Joeri Sol, Social Interaction, Co-Worker Altruism, and Incentives, November 2008

2477 Gaëtan Nicodème, Corporate Income Tax and Economic Distortions, November 2008

2478 Martin Jacob, Rainer Niemann and Martin Weiss, The Rich Demystified - A Reply to Bach, Corneo, and Steiner (2008), November 2008

2479 Scott Alan Carson, Demographic, Residential, and Socioeconomic Effects on the Distribution of $19^{\text {th }}$ Century African-American Stature, November 2008

2480 Burkhard Heer and Andreas Irmen, Population, Pensions, and Endogenous Economic Growth, November 2008

2481 Thomas Aronsson and Erkki Koskela, Optimal Redistributive Taxation and Provision of Public Input Goods in an Economy with Outsourcing and Unemployment, December 2008

2482 Stanley L. Winer, George Tridimas and Walter Hettich, Social Welfare and Coercion in Public Finance, December 2008

2483 Bruno S. Frey and Benno Torgler, Politicians: Be Killed or Survive, December 2008

2484 Thiess Buettner, Nadine Riedel and Marco Runkel, Strategic Consolidation under Formula Apportionment, December 2008

2485 Irani Arraiz, David M. Drukker, Harry H. Kelejian and Ingmar R. Prucha, A Spatial Cliff-Ord-type Model with Heteroskedastic Innovations: Small and Large Sample Results, December 2008

2486 Oliver Falck, Michael Fritsch and Stephan Heblich, The Apple doesn't Fall far from the Tree: Location of Start-Ups Relative to Incumbents, December 2008

2487 Cary Deck and Harris Schlesinger, Exploring Higher-Order Risk Effects, December 2008

2488 Michael Kaganovich and Volker Meier, Social Security Systems, Human Capital, and Growth in a Small Open Economy, December 2008

2489 Mikael Elinder, Henrik Jordahl and Panu Poutvaara, Selfish and Prospective: Theory and Evidence of Pocketbook Voting, December 2008 
2490 Maarten Bosker and Harry Garretsen, Economic Geography and Economic Development in Sub-Saharan Africa, December 2008

2491 Urs Fischbacher and Simon Gächter, Social Preferences, Beliefs, and the Dynamics of Free Riding in Public Good Experiments, December 2008

2492 Michael Hoel, Bush Meets Hotelling: Effects of Improved Renewable Energy Technology on Greenhouse Gas Emissions, December 2008

2493 Christian Bruns and Oliver Himmler, It's the Media, Stupid - How Media Activity Shapes Public Spending, December 2008

2494 Andreas Knabe and Ronnie Schöb, Minimum Wages and their Alternatives: A Critical Assessment, December 2008

2495 Sascha O. Becker, Peter H. Egger, Maximilian von Ehrlich and Robert Fenge, Going NUTS: The Effect of EU Structural Funds on Regional Performance, December 2008

2496 Robert Dur, Gift Exchange in the Workplace: Money or Attention?, December 2008

2497 Scott Alan Carson, Nineteenth Century Black and White US Statures: The Primary Sources of Vitamin D and their Relationship with Height, December 2008

2498 Thomas Crossley and Mario Jametti, Pension Benefit Insurance and Pension Plan Portfolio Choice, December 2008

2499 Sebastian Hauptmeier, Ferdinand Mittermaier and Johannes Rincke Fiscal Competition over Taxes and Public Inputs: Theory and Evidence, December 2008

2500 Dirk Niepelt, Debt Maturity without Commitment, December 2008

2501 Andrew Clark, Andreas Knabe and Steffen Rätzel, Boon or Bane? Others' Unemployment, Well-being and Job Insecurity, December 2008

2502 Lukas Menkhoff, Rafael R. Rebitzky and Michael Schröder, Heterogeneity in Exchange Rate Expectations: Evidence on the Chartist-Fundamentalist Approach, December 2008

2503 Salvador Barrios, Harry Huizinga, Luc Laeven and Gaëtan Nicodème, International Taxation and Multinational Firm Location Decisions, December 2008

2504 Andreas Irmen, Cross-Country Income Differences and Technology Diffusion in a Competitive World, December 2008

2505 Wenan Fei, Claude Fluet and Harris Schlesinger, Uncertain Bequest Needs and LongTerm Insurance Contracts, December 2008

2506 Wido Geis, Silke Uebelmesser and Martin Werding, How do Migrants Choose their Destination Country? An Analysis of Institutional Determinants, December 2008 